九州大学学術情報リポジトリ

Kyushu University Institutional Repository

\title{
Continuous Hydrolysis of Starch in Membrane Unit Connected Immobilized Enzyme Reactor
}

Uttapap, Dudsadee

Laboratory of Microbial Technology, Faculty of Agriculture, Kyushu University

Koba, Yojiro

Laboratory of Microbial Technology, Faculty of Agriculture, Kyushu University

Ishizaki, Ayaaki

Laboratory of Microbial Technology, Faculty of Agriculture, Kyushu University

https://doi.org/10.5109/23926

出版情報：九州大学大学院農学研究院紀要. 33 (3/4)，pp.167-175，1989-03. Kyushu University バージョン：

権利関係 : 


\title{
Continuous Hydrolysis of Starch in Membrane Unit Connected Immobilized Enzyme Reactor
}

\author{
Dudsadee Uttapap, Yojiro Koba and Ayaaki Ishizaki \\ Laboratory of Microbial Technology, Faculty of Agriculture, \\ Kyushu University 46-09, Fukuoka 812, Japan.
}

(Received July 19, 1988)

\begin{abstract}
Use of tangential flow filtration unit (TFFU) for separation of immobilized glucoamylase particles in hydrolysis of soluble starch through a continuous mode was studied. Both the filtration rate and reducing sugars, produced as the result of enzymatic hydrolysis, decreased with the filtration time. The filtration rate at various starch concentration within 40 hours seemed to fit best into an exponential equation with a constant filtration rate at infinite time and steady state may finally be reached at a certain value. When the system was operated for 8 days, apparent filtration rate of the first 2 days can fit well with the exponential equation. The $F_{a}$ and coefficient of determination were $35 \mathrm{ml} / \mathrm{h}$ and 0.985 , respectively. But after that it did not follow the assumption. The temperature was found to influence the filtration rate. Increasing in filtration rate along with increasing temperature was probably due to decreasing retrogradation of soluble starch at high temperature. Preliminary study of prefiltration found that the slurry which passed the prefilter gave a higher filtration rate in TFFU compared to nonprefiltrated slurry.
\end{abstract}

\section{INTRODUCTION}

The use of tangential flow filtration unit for separation of immobilized glucoamylase particles in starch hydrolysis system had been studied by Uttapap et al. (in press). The batchwise experiment showed that almost all of total resistances of filtration is related to insoluble materials, its significant part consists of the resistance caused by insoluble materials deposited on a surface of membrane and boundary layer. For the purpose of setting up the practical membrane separator, it is necessary to minimize the formation of insoluble materials deposited on the surface and boundary layer of the membrane so that the filtration rate does not significantly decline with time. Methods for reducing the formation of these deposits were reported by Le $\boldsymbol{e t}$ al. (1985), Lee et al. (1976), Matsumoto et al. (1987) and Blatt et al. (1970).

The insoluble materials in this system consist of immobilized glucoamylase particles and starch gel. The content of immobilized glucoamylase particles are constant while starch gel is dependent on extent of enzyme reaction. This investigation is to study the effect of some parameters such as temperature and starch concentration on enzyme reaction which consequently affect the rate of membrane filtration. The experiments were conducted in continuous stirred reactor. The glucose product obtained was continuously removed by mean of tangential flow filtration unit. The effect of recirculating flow rate on membrane performance was also investigated. The feasibility of prefilter for reduction of immobilized glucoamylase particles content in reacting slurry before separation with membrane filter was studied. The character. 
istics of tangential flow filtration of reacting slurry with the prefilter were compared to the filtration without the prefilter.

\section{MATERIALS AND METHODS}

\section{Enzyme and substrate}

The commercial grade of glucoamylase obtained from Aspergillus niger (supplied by NOVO industri A/S, Denmark) as a liquid form was used. No further treatment was done before use. The substrates used were soluble starch and dextrin purchased from Nakarai Chemical Ltd., Osaka, Japan.

\section{I mmobilization method}

The industrial glucoamylase preparation was covalently grafted onto corn stover by the method described by Vallat et al. (1986). The reaction was carried out with 20 $\mathrm{g}$ corn stover in a $1,000 \mathrm{ml}$ stirred container. The process included oxidation : $500 \mathrm{ml}$ of $0.2 \mathrm{M}$ sodium metaperiodate solution in distilled water at $25^{\circ} \mathrm{C}$ for 30 hours in the dark, amination : $500 \mathrm{ml}$ of $2.7 \mathrm{M}$ ethylene diamine solution in distilled water at $25^{\circ} \mathrm{C}$ for 70 hours, reduction : $500 \mathrm{ml}$ of $5 \mathrm{~g} / \mathrm{Z}$ sodium cyanoborohydride solution in $0.05 \mathrm{M}$ phosphate buffer, $\mathrm{pH} 6.5$, at $25^{\circ} \mathrm{C}$ for 3 hours, activation : $500 \mathrm{ml}$ of $3 \%$ glutaraldehyde solution in $0.05 \mathrm{M}$ pyrophosphate buffer, $\mathrm{pH} 6.5$, at $25^{\circ} \mathrm{C}$ for 18 hours, and immobilization : $500 \mathrm{ml}$ of $12.6 \mathrm{~g} / \mathrm{Z}$ glucoamylase solution in $0.1 \mathrm{M}$ sodium acetate buffer, $\mathrm{pH} 5.5$, at $4^{\circ} \mathrm{C}$ for 40 hours.

\section{Soluble enzyme assay}

Glucoamylase activity was assayed as follows. A solution of $7 \mathrm{ml}$ of $1 \%$ boiled soluble starch in $0.1 \mathrm{M}$ sodium acetate buffer $(\mathrm{pH} 4.5)$ was preincubated at $40^{\circ} \mathrm{C}$ for 10 min. Then $1 \mathrm{ml}$ of suitably diluted enzyme solution was added and mixed. After 10 min reaction, $1 \mathrm{ml}$ of the reaction mixture was withdrawn and the amount of glucose liberated was determined by micro-Bertrand method (Pringsheim et al., 1932). One unit of glucoamylase activity is defined as the amount of enzyme which produced 1 micromole glucose in $1 \mathrm{~min}$ under the conditions described above.

\section{I mmobilized enzyme assay}

Well mixed suspension of immobilized enzyme in deionized water, having concentration of $2.46 \mathrm{mg} / \mathrm{ml}$ and $15 \mathrm{ml}$ of $1 \%$ boiled soluble starch in $0.1 \mathrm{M}$ sodium acetate buffer $\left(\mathrm{pH} \mathrm{3.5)}\right.$ were preincubated at $40^{\circ} \mathrm{C}$ for $10 \mathrm{~min}$. After that $1 \mathrm{ml}$ of enzyme suspension was added into starch solution. The reaction was conducted in a shaker bath at $40^{\circ} \mathrm{C}$ for $20 \mathrm{~min}$, and stopped by adding $2 \mathrm{ml}$ of $1 \mathrm{M} \mathrm{NaOH}$ solution. The glucose content in supernatant separated by centrifugation was analyzed.

\section{Experimental apparatus system}

A schematic diagram of experimental apparatus system contained of the tangential flow filtration unit (TFFU) and immobilized enzyme reactor as shown in Fig. 1. The reactor was maintained at constant temperature in a water bath. The $400 \mathrm{ml}$ of reacting slurry consisting of $5 \%$ soluble starch, $0.159 \% \mathrm{CaCl}_{2}, 0.159 \%$ acetic acid, 0 . $017 \%$ sodium acetate, and immobilized glucoamylase $2.213 \mathrm{~g}$ was agitated with a 


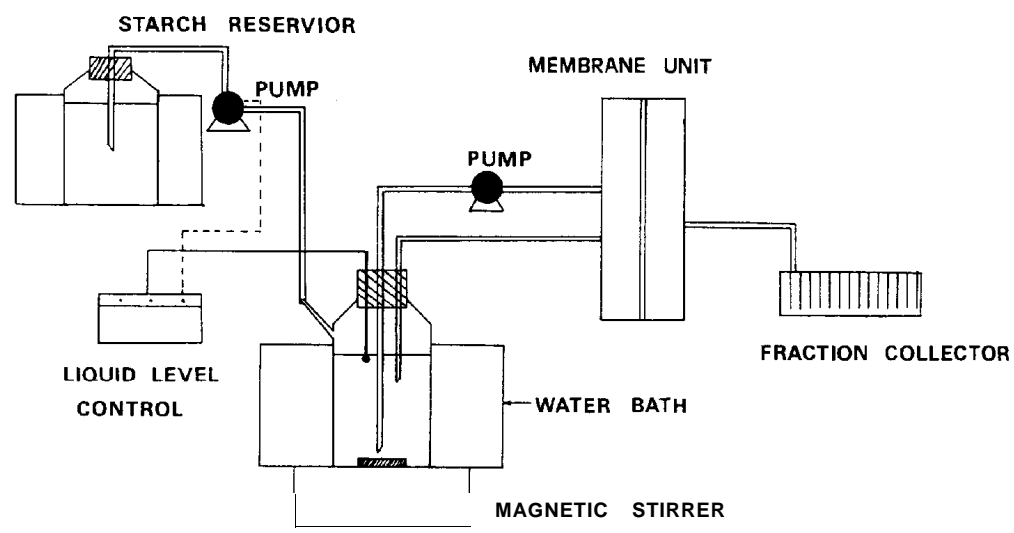

Fig. 1. Schematic diagram of the experimental apparatus.

magnetic stirrer. The $\mathrm{pH}$ of the slurry was 3.5. After 3 hours of hydrolysis, the slurry was pumped at a flow rate of $26.9 \mathrm{ml} / \mathrm{min}$ through the membrane filtration unit to separate produced glucose from immobilized enzyme. Continuous feed and product removal were accomplished when the passage of filtrate resulted in a drop of the liquid level in the reactor. Thus the activated liquid level probe will turn a feed pump to fill fresh substrate into enzyme reactor. The filtrate was collected in small glass tubes by a fraction collector. The details of membrane apparatus and type of membrane filter used has been described in the earlier report. (Uttapap et al., in press)

\section{RESULT AND DISCUSSION}

\section{Continuous starch hydrolysis}

The enzyme used was prepared by immobilization of glucoamylase onto corn stover having size of less than 44 micron. The immobilized enzyme obtained has an activity of $3,060 \mathrm{U} / \mathrm{g}$ dry weight with activity yield of $24.22 \%$. Filtration rates obtained during the continuous hydrolysis of soluble starch at various concentration in a TFFU connected immobilized enzyme reactor at $40^{\circ} \mathrm{C}$ are presented in Fig. 2. The filtration rate is dependent on concentration of starch. The lower concentration gave higher filtration rate. However, the filtration characteristics are similar for all starch concentrations. A rapid decline in the filtration rate was observed during early stage and followed by a slow decline upon further filtration. Such an initial decrease in filtration rate is attributed to the rapid deposition of immobilized enzyme particles at the surface of membrane, following by gradually increase in thickness of this layer by starch gel. It is postulated that the filtration rate is affected by two main types of particles, immobilized glucoamylase particles and starch gel. In these system, the content of immobilized glucoamylase is constant. Thus the difference of filtration rate resulted from the starch gel. Fig. 2 also shows the percentage of hydrolysis. Percentage of hydrolysis of 1 and $2 \%$ starch is almost the same, while that of 5 and $10 \%$ is lower, At high starch concentration such as $10 \%$, a significant amount of starch remained in the slurry resulted in a large formation of the layer thickness on surface of membrane. Thus the filtration rate at such high concentration was lower than that 


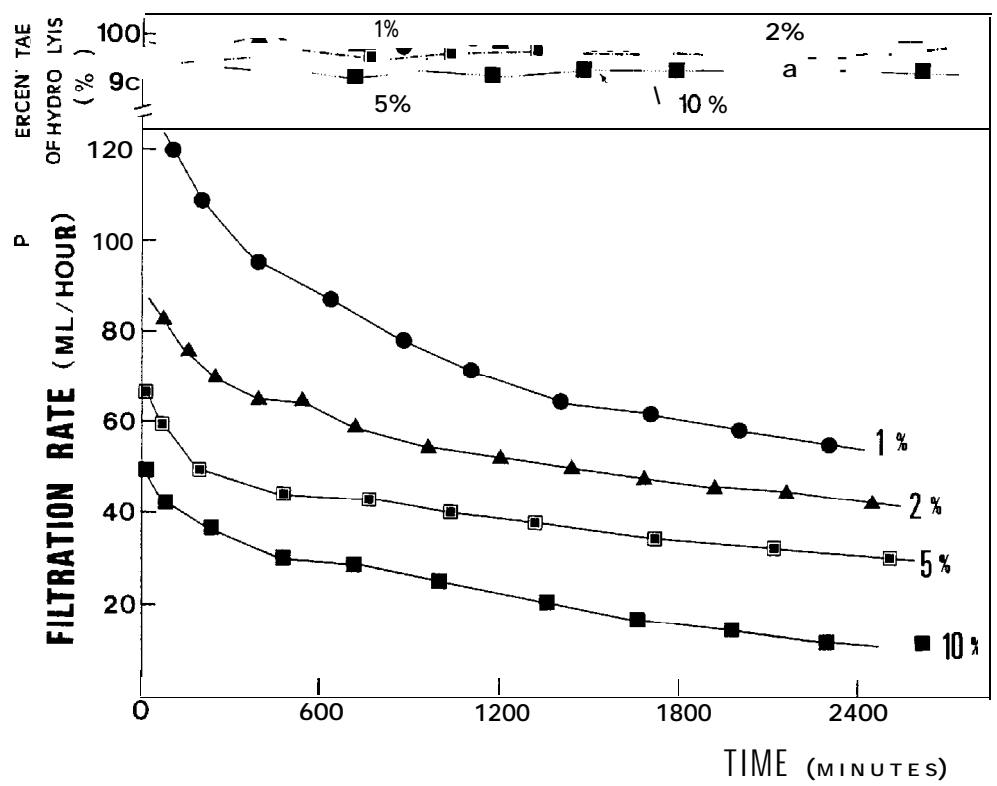

Fig. 2. Effect of starch concentration on the filtration rate and percentage of hydrolysis in the TFFU connected enzyme reactor.

at low starch concentration.

All data obtained on filtration rate measurement seemed to fit satisfactorily into an exponential equation (Eq. 1) with a constant filtration rate at infinite time.

$$
F=\left(F_{0}-F_{\alpha}\right) e^{-K t}+F_{\alpha}
$$

where $\mathrm{F}=$ Filtration rate at any time

$F_{0}=$ Filtration rate at $t=0$

$F_{\alpha}=$ Filtration rate at $t=\mathrm{a}$

$K=$ Time constant

$t=$ Time

Constant filtration rate at infinite time of each starch concentration was assumed and corresponding values for intercept, slope and coefficient of determination were calculated by the least squares method using Eq. 2 :

$$
\ln \left(F-F_{a}\right)=\ln \left(F_{0}-F_{a}\right)-K t
$$

The calculated values are shown in Table 1 and corresponding straight lines of Eq. 2 are shown in Fig. 3. The plot of $\ln \left(F-F_{a}\right)$ and time can be divided into 2 stages ; the early stage in which filtration rate decreased rapidly and the second stage in which filtration rate is fit to the exponential equation. From the results in Table 1, it can be postulated that a steady state may finally reached to a certain value for each starch concentration. At that point, the thickness of deposited layer seemed to arrive the saturated value. Fig. 4 shows the accumulated reducing sugar in filtrate as a function of time. Accumulated reducing sugar of 5\% starch has a tendency to approach the value of $10 \%$ starch. The hydrolysis of $5 \%$ starch found to be the most efficient 
Table 1. Calculations for the intercept, slope and coefficient of determination of the straight line $\left[\ln \left(\mathrm{F}-F_{\alpha}\right)=\ln \left(F_{0}-F_{\alpha}\right)-K t\right]$, assuming different $F_{\alpha}$ values, in the TFFU.

\begin{tabular}{ccccc}
\hline $\begin{array}{c}\text { Starch } \\
\text { Concentration (\%) }\end{array}$ & $\begin{array}{c}\text { Assumed } \\
F_{a}\end{array}$ & $\begin{array}{c}\text { Intercept } \\
\ln \left(F_{0}-F_{a}\right)\end{array}$ & $\begin{array}{c}\text { Slope } \\
(K)\end{array}$ & $\begin{array}{c}\text { Coefficient of } \\
\text { Determination }\left(r^{2}\right)\end{array}$ \\
\hline 1 & 49 & 4.3140 & -0.0011 & 0.9970 \\
2 & 38 & 3.7462 & -0.0009 & 0.9900 \\
5 & 26 & 3.4028 & -0.0008 & 0.9812 \\
10 & 3 & 3.6784 & -0.0006 & 0.9897 \\
\hline
\end{tabular}

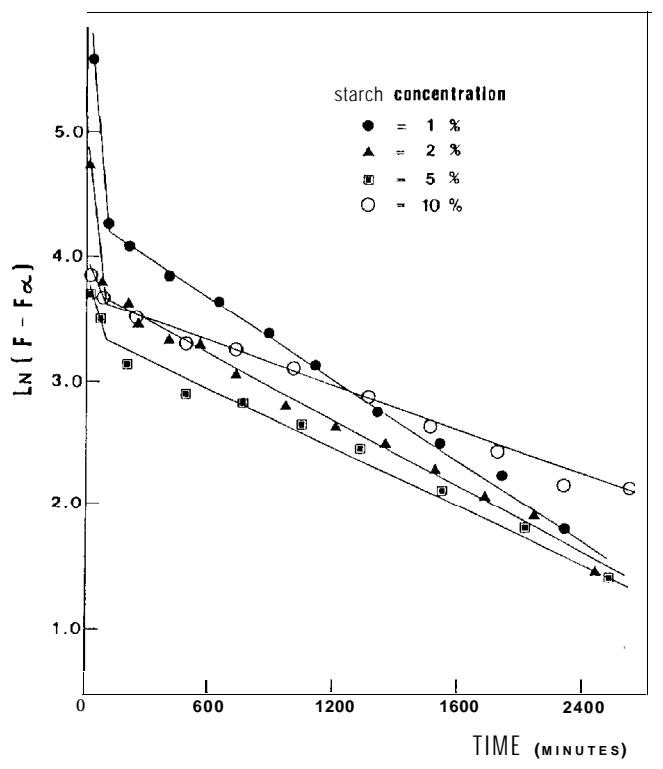

Fig. 3. The linear relationship between the values of the filtration rate minus the calcurated constant filtration rate $\left[\mathrm{Ln}\left(\mathrm{F}-F_{a}\right)\right]$ and time at various concentration of starch.

condition in TFFU connected enzyme reactor, since its filtration rate can reach a steady state at appreciable value. However, these experiments were done in a short time operation (40 hours). A long time operation ( 8 days) was set in order to prove this assumption. The operating temperature was $50^{\circ} \mathrm{C}$. As shown in Fig. 5, the experimental filtration rate followed the assumption for the first 2 days and the apparent filtration rate was almost equal to the predicted value $\left(r^{2}=0.985\right.$ and $\left.F_{\alpha}=35 \mathrm{ml} / \mathrm{h}\right)$. After that apparent rate gradually decreased, while the predicted rate is constant. It means that the exponential equation can apply to the experimental data in the limited period. The reason that the apparent rate was lower than the predicted value in the latter period is due to increasing in viscosity. Figure 2 shows that percentage of hydrolysis of 5\% starch was around 94\%. This indicated the remaining of indigestible starch which consequently increased in viscosity. When $5 \%$ dextrin was used instead of soluble starch (Fig. 6), it was found that filtration rate was about the rate of starch at early stage, but later it was far different. Filtration rate of dextrin was about 4 


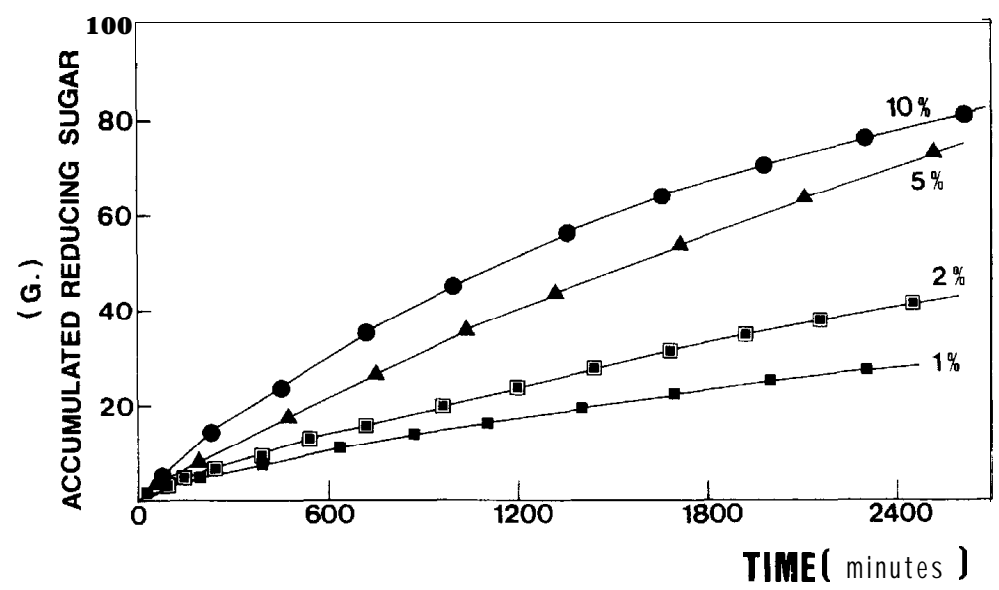

Fig. 4. Accumulated reducing sugar obtained from the starch hydrolysis in TFFU connected enzyme reactor at various concentration of starch.

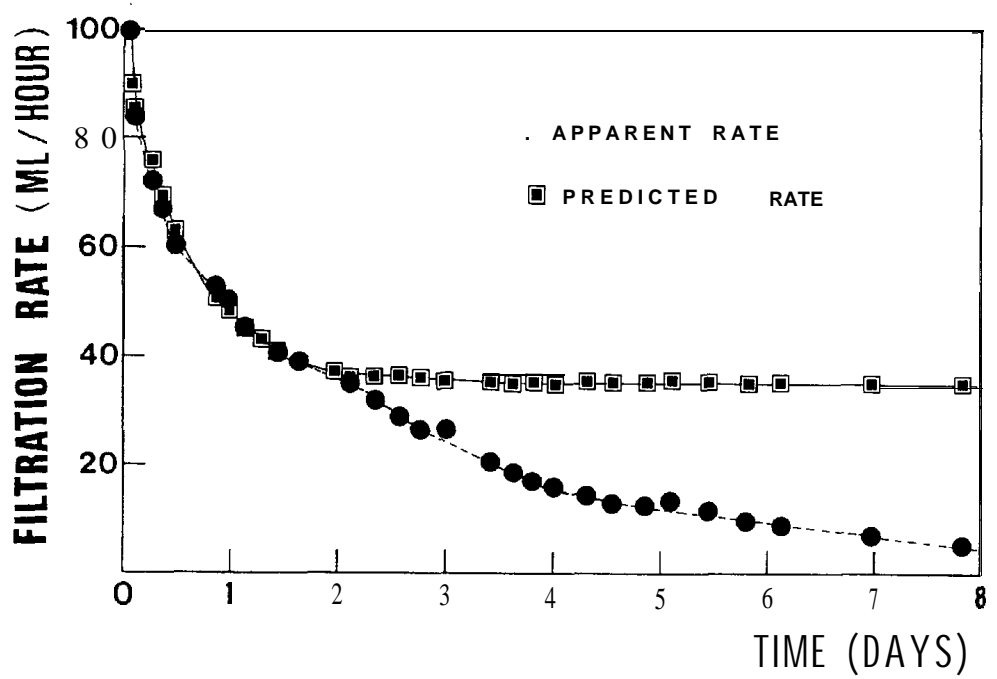

Fig. 5. Comparison of apparent filtration rate with predicted filtration rate calculated from Eq. 2.

times of starch on day 8. Because starch solution is more viscous than dextrin.

\section{Effect of temperature on filtration rate}

As shown in Fig. 7, the filtration rate increased with increasing temperature. The temperature seemed to have more significant effect on filtration rate than the concentration of starch remained in the slurry. It was asserted by the fact as follows :(1) at $60^{\circ} \mathrm{C}$, the filtration rate still high though the percentage of hydrolysis was low ; (2) the percentage of hydrolysis at 40 and $50^{\circ} \mathrm{C}$ is nearly the same, but filtration rate at $50^{\circ} \mathrm{C}$ was higher. The increase of filtration rate along with increasing the temperature was 


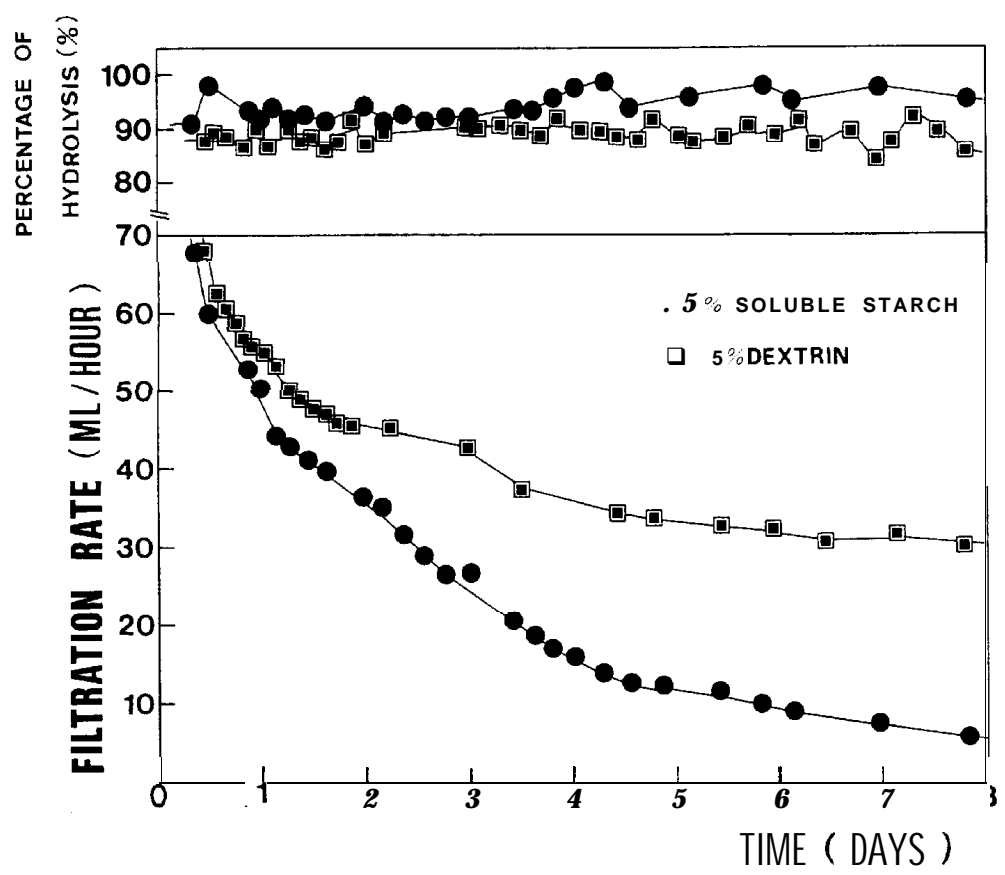

Fig. 6. Filtration rate and percentage of hydrolysis of 5\% dextrin compared with 5\% soluble starch in TFFU connected enzyme reactor.

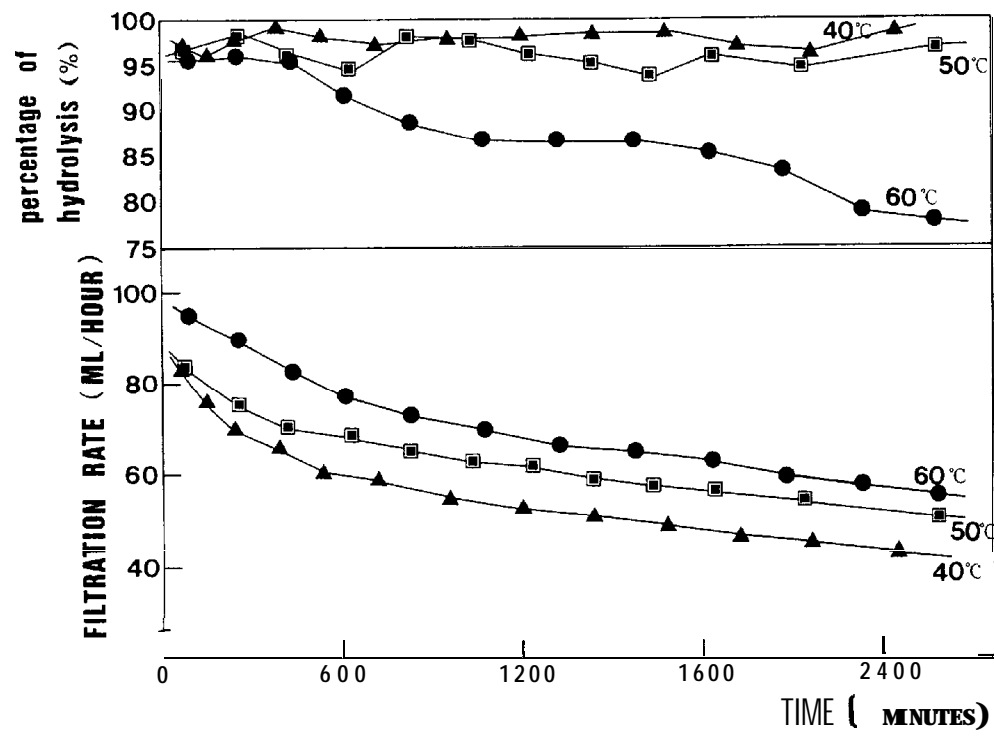

Fig. 7. Effect of temperature of the filtration rate and percentage of hydrolysis in the TFFU connected enzyme reactor. 
probably due to decreasing retrogradation of soluble starch at high temperature. The lower thickness of deposited layer thus enhanced in increasing the filtration rate.

\section{Study of prefilter}

In order to maximize the inlet velocity of feed solution into membrane device, the inlet port had been designed to use a small size tube. When the system was operated for a long time, blockage of inlet port and pipe line may occur, since the slurry used is heavy in concentration of immobilized glucoamylase. The best method to prevent this problem may be prefiltration. The prefiltration may also enhance the filtration rate of TFFU. In this study, the prefilter made from polypropylene having pore size of 0.7 micron was used. The slurry in which $2.84 \mathrm{~g}$ of corn stover was suspended in 500 $\mathrm{ml}$ of $9 \%$ glucose solution was passed through the prefilter, and then, prefiltrate obtained was filtered in TFFU. The filtration rate was measured and compared to the filtration rate of slurry without prefiltration. The data presented in Figure 8 shows that at low recirculating flow rate, the filtration rate of both slurries was not significantly different. Whereas at high recirculating flow rate, the prefiltrated slurry gave a higher filtration rate compared to the non-prefiltrated slurry. This can be explained that at low recircurating flow rate, shear force acting on the surface of membrane is too small to have a significant effect on moving back of particles from surface of membrane to bulk solution. In contrast with high recirculating flow rate, shear force is big enough to move the particles. Since particles passed together with prefiltrate are small in size, then moving back to bulk solution was easier than large particles in the slurry. The lower resistance to filtration in the case of application of prefilter thus resulted in higher filtration rate compared to the slurry without

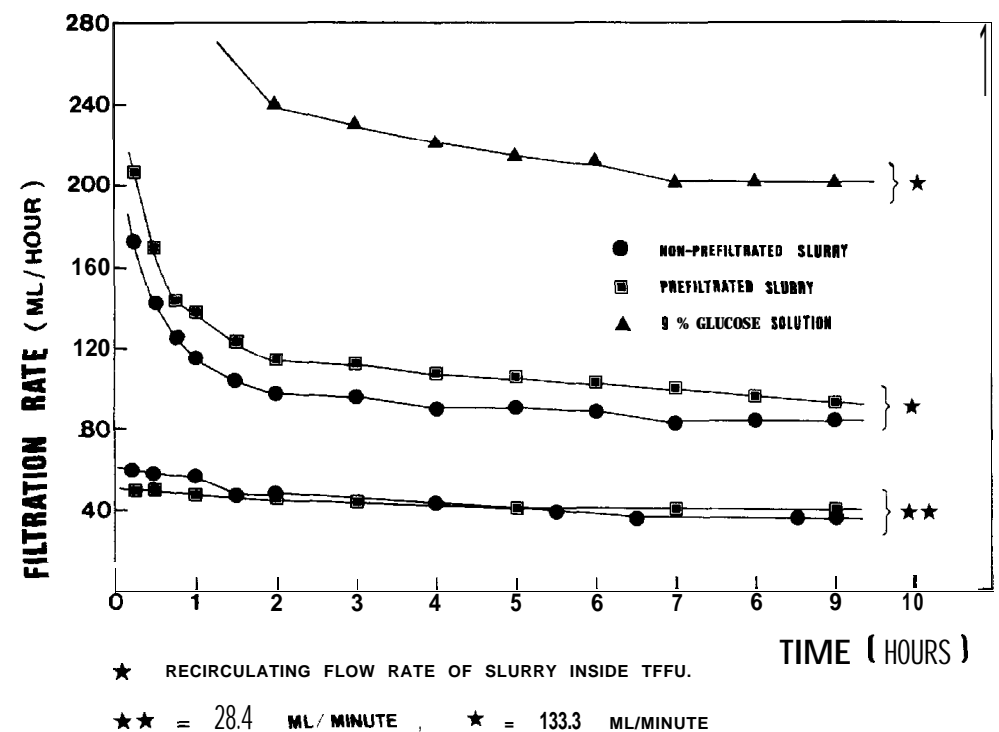

Fig. 8. Filtration rate of the glucose solution, non-prefiltrated slurry and prefiltrated slurry in TFFU at different recirculation flow rate. (The slurry consisting of corn stover powder, $2.84 \mathrm{~g}$, in $500 \mathrm{ml}$ of $9 \%$ glucose solution) 
prefiltration.

\section{CONCLUSION}

It was found that filtration rate of the slurry in the TFFU connected enzyme reactor can not reach the steady state value. Prefiltration enhanced the filtration rate, but it was not so efficient as expected. Thus to solve the problem completely, the further study should be required.

\section{REFERENCES}

Blatt, W. F., A. Dravid, A. S. Michaels and L. Nelson 1970 Solute polarization and cake formation in membrane ultrafiltration: Causes, consequences, and control techniques In "Membrane Science and Technology", ed. by E. Flinn, Plenum Press, New York-London. pp. 47-97.

Le, M. S. and T, Atkinson 1985 Crossflow microfiltration for recovery of intracellular products. Process Biochem., 19:26-31

Lee, D. N. and R. L. Merson 1976 Chemical treatment of cottage cheese whey to reduce fouling of ultrafiltration membranes. J. Food Sci., $41: 778-786$

Matsumoto, K., S. Katusuyama and H. Ohya 1987 Separation of yeast by cross-flow filtration with backwashing. J. Ferment. Technol., $65: 77-83$

Pringsheim, V. H. and J. Leibowitz 1932 Einfache Kohlehydrate In "Handbuch der Pflanzenanalyse", ed. by G. Klein, Verlag Von Julius Springer, Wien, pp. 786

Uttapap, D., Y. Koba and A. Ishizaki Recycle use of immobilized glucoamylase by tangential flow filtration unit. Biotech. Bioeng. (in press)

Vallat, I. and P. Monsan 1986 Maltodextrin hydrolysis in a fluidized-bed immobilized enzyme reactor. Biotech. Bioeng., $28: 151-159$ 